\title{
Variation in Sclerotinia sclerotiorum Bean Isolates from Multisite Resistance Screening Locations
}

Lindsey Otto-Hanson, Plant Pathology Department, University of Minnesota, St. Paul 55108; James R. Steadman and Rebecca Higgins, Department of Plant Pathology, and Kent M. Eskridge, Department of Statistics, University of Nebraska, Lincoln 68583

\begin{abstract}
Otto-Hanson, L., Steadman, J. R., Higgins, R., and Eskridge, K. M. 2011. Variation in Sclerotinia sclerotiorum bean isolates from multisite resistance screening locations. Plant Dis. 95:1370-1377.

There is no complete resistance to Sclerotinia sclerotiorum, cause of white mold in dry bean (Phaseolus vulgaris). Variable resistance expression is one problem in screening for improved white mold resistance. With no previous information in the literature, pathogen variation in multisite screening nurseries was evaluated as one cause of diverse resistance expression. In all, 10 isolates of $S$. sclerotiorum used in greenhouse screening and 146 isolates collected from nine white mold field screening nurseries in major bean production areas in the United States were compared using mycelial compatibility groupings (MCGs) and an aggressiveness test. These 10 greenhouse screening isolates formed six MCGs. Among 156 field and greenhouse isolates,

64 MCGs were identified and 36 of those were each composed of a single unique isolate. Significant differences in isolate aggressiveness were found between some isolates in different MCGs but the isolates within an MCG did not differ in aggressiveness. High isolate variation found within and between field locations could influence the disease phenotype of putative white mold resistant germplasm. We next compared genotype and phenotype of isolates from screening nurseries and those from producer fields. Variability found in and among screening locations did reflect variability found in the four producer fields sampled. White mold resistance screening can be improved by knowledge of isolate genotypic and phenotypic characteristics.
\end{abstract}

Sclerotinia sclerotiorum (Lib.) de Bary, cause of white mold on dry bean, is among the most devastating and promiscuous necrotrophic fungal plant pathogens. S. sclerotiorum has a wide geographic distribution and diverse host range consisting of over 400 plant species, causing severe yield losses in many important agronomic crops, but it also includes many weed species among its hosts (15). Some other important crops affected are sunflower, soybean, oilseed rape, peanut, dry pea, and lettuce $(4,5)$.

Management of $S$. sclerotiorum can be problematic. Planting a white-mold-resistant cultivar would be the most cost-effective and least intensive management strategy for dry and green bean Phaseolus vulgaris producers. A major detriment to the resistance control strategy for this pathogen is the lack of high levels of broad resistance in the majority of its host plants $(3,5,34)$. Because disease outbreaks are usually sporadic in fields (especially ascosporeinitiated disease) and the dispersal of the pathogen in a field is usually aggregated, screening putative sources of host plant resistance under field conditions can be challenging, especially without irrigation and artificial inoculation (5).

Dry bean producers in the Northern Great Plains of the United States and in Michigan have rated white mold as the most serious bean disease $(27,39)$. Bean cultivars grown in temperate regions under irrigation can suffer greater losses under $S$. sclerotiorum attack (e.g., the pinto bean, which is the most important dry bean class in the United States; 28). Similar to other host species of $S$. sclerotiorum, a lack of broad resistance sources slows progress in breeding for improved bean lines. Kolkman and Kelly (23) found that genetic resistance in dry bean is quantitatively inherited and complex because it consists of both disease avoidance and physiological mechanisms. Avoidance is manifested in upright and less dense canopies that create a less conducive microclimate for $S$. sclerotiorum to colonize blossoms and infect the stems $(23,29,33)$.

Corresponding author: L. Otto-Hanson, E-mail: hans3583@umn.edu

Accepted for publication 28 April 2011.

doi:10.1094/PDIS-11-10-0865

(C) 2011 The American Phytopathological Society
Greenhouse or laboratory screening methods detect physiological mechanisms better than field tests because they directly challenge the resistance of a bean line, and can identify "escapes" that had been identified in the field as resistant.

Multisite screening is a collaborative effort in which bean breeders and pathologists from major production areas in the United States each screen new putative sources of white mold resistance, with the same evaluation methods for greenhouse and field tests (30,35-37). Screening for broad disease resistance across multiple locations incorporates variable environments for disease development or variable aggressiveness of the pathogen population across locations (8). Variable environments can be used to test for genotype-environment interactions, with the across-site requirement that nurseries are managed to promote white mold. In general, disease is favored when bean crops are managed to maximize yield (34).

Kull et al. (26) suggested that the range in aggressiveness of $S$. sclerotiorum isolates in agricultural populations may impact cultivar performance. Pathogen variability could contribute to the low correlation between greenhouse and field screening tests across sites, and variability in isolate aggressiveness has been associated with problems in evaluating and breeding for resistance in host crops $(7,24,25)$. Our isolates collected from multisite nurseries provide opportunities to study pathotype aggressiveness among different screening locations.

In previous $S$. sclerotiorum variation studies, mycelial compatibility groupings (MCGs) were a tool that has been used to determine the genetic variation among pathogen isolates. MCGs have been used to determine pathogen variability in isolates of $S$. sclerotiorum from cabbage, canola, giant buttercup, cauliflower, soybean, and dry bean in the United States, Canada, Australia, and New Zealand $(7,9,11,13,17,19,21,22)$. The MCG system is an assay of self and nonself recognition controlled by multiple loci $(5,6)$ and is a good test for intraspecific heterogeneity in S. sclerotiorum. Researchers have suggested that MCGs are genotypically unique (i.e., they represent genetically different individuals; 11,22) but have not been reported to relate to a phenotype. Factors for MCGs were found to be stable and unchanging through successive sexual generations and after serial culturing, and the correlation between an MCG and a DNA fingerprint supports the synonymous relation- 
ships between MCGs and clones of S. sclerotiorum (19,25). MCGs of $S$. sclerotiorum have persisted from year to year, covering wide geographic areas $(11,14)$. Although information on S. sclerotiorum clonality is of interest to breeders and plant pathologists, it becomes more relevant if the genetic variation is related to variation in pathogen aggressiveness.

After much debate over the definition of pathogen aggressiveness, Pariuad et al. (31) coined the simplest definition, compatible with most cited papers: the quantitative variation of pathogenicity on susceptible hosts. There are many different ways to measure pathogen aggressiveness: infection efficiency, latent period, spore production rate, infectious period, and lesion size (31). In this article, pathogen aggressiveness of $S$. sclerotiorum was measured by stem lesion size. When pathogen aggressiveness of S. sclerotiorum isolates was compared previously, no or small differences were found among isolates. Due to consistent reports of the lack of differences in aggressiveness among pathogen isolates of S. sclerotiorum, many reports focused only on genotypic characterization of S. sclerotiorum isolates by use of MCGs or molecular markers. When isolates from potato fields in the Columbia Basin of Washington were inoculated by attaching blossoms colonized by $S$. sclerotiorum to stems of potato plants, no significant differences in aggressiveness among isolates were observed (2). There was no correlation between clone frequency and aggressiveness of $S$. sclerotiorum in greenhouse tests of isolates collected from Ontario to northern Alberta, though the population was genetically heterogeneous (3). The frequency of clones with high or low aggressiveness within a producer field would be useful in the evaluation of the risk of high infection and the selection of clones that could be used for resistance screening. A lack of variation in virulence among isolates from agricultural populations in defined geographical areas has been reported in a number of studies (5). However, Durman et al. (11) found that isolates collected from sunflower plants were more aggressive than those collected from soybean and, when isolates were tested on sunflower in Australia, significant differences were found but only a few isolates exhibited high or low aggressiveness, which may have skewed results (12). Bolton et al. (5) suggested that differences in aggressiveness may be discovered when comparing isolates from widely separated geographical regions. Kull et al. (25) identified differences in aggressiveness in soybean field isolates from Illinois and stressed the importance of examining the aggressiveness of S. sclerotiorum isolates within naturally infested disease screening nurseries to explain the mixed results reported across locations used for resistance screening trials.

No previous studies have addressed variation in S. sclerotiorum isolates from field nurseries and greenhouse tests that are used to screen for resistance. In fact, there is a dearth of information on pathogen aggressiveness or genetic variation available for multisite resistance screening for any soilborne necrotroph. Thus, the hypotheses being tested are (i) genetic (MCGs) and phenotypic (aggressiveness) variation exists in S. sclerotiorum isolates collected from screening nurseries and greenhouse tests throughout major bean-producing regions of the United States, France, and Mexico; (ii) genotypic and phenotypic variation also exists among $S$. scle- rotiorum isolates collected from bean producer fields in major production regions; and (iii) differences in aggressiveness can be detected among identified MCGs.

\section{Materials and Methods}

Collection of screening isolates. To evaluate the populations of $S$. sclerotiorum in screening nurseries across major bean production areas in North America and France, sclerotia of S. sclerotiorum isolates were collected from individual dry bean lines grown in nine bean screening nurseries in North America and France (as an outlier). Additional isolates were collected from public and private field sites in Nebraska, Michigan, Oregon, Minnesota, France, Mexico, North Dakota, California, and Washington from 2003 to 2005. The number of samples collected each year was dependent on whether the environment was suitable for white mold and, thus, sclerotial development. This study was unique in that samples were not randomly or statistically sampled from random bean fields; instead, isolates were collected from specific bean cultivars replicated in the white mold field screening sites at each location. Isolates were collected from the same three bean host cultivars that varied in degrees of white mold susceptibility. Each screening nursery had 12 entries planted in three replicate $(4.5 \mathrm{~m})$ rows of a multisite screening study. Among the 12 entries were the three host cultivars 'G122', a cranberry seed type with partial resistance; 'Bunsi', a navy bean seed type with lower susceptibility related to escape or avoidance in the field; and 'Beryl', a great northern seed type that is susceptible to white mold. Under ideal conditions for white mold development at a location, one to three sclerotia were collected from each row of the three cultivars in each of the three replications, for a maximum of nine samples per year. In all cases except Mexico, all screening samples were collected from the same screening nursery each year. In the Sinoloa Valley in Mexico, isolates were collected from two fields in the same year. In total, 146 isolates were collected from nine different locations. The standard screening isolates used in cooperator greenhouse or laboratory tests were also collected from Nebraska, North Dakota, New York, Michigan, Oregon, Washington, Colorado, Idaho, and Wisconsin. Control isolate 1980 from Nebraska and the isolate of $S$. sclerotiorum that was sequenced were added for a total of 10 greenhouse screening isolates (Table 1). The 9 greenhouse screening isolates were added to the 146 field screening isolates for a total of 156 isolates.

Collection of producer field isolates. In 2007, isolates of $S$. sclerotiorum were collected from producer fields in Nebraska, North Dakota, Colorado, and Washington. Isolates were collected based on the sampling strategy of Jochua et al. (16), who used the cost of sampling fields and the variance of the virulence found in Uromyces appendiculatus in a given field location to determine how many samples should be collected within and among dry bean fields. However, instead of using cost as the determinant for sampling, we substituted time for cost and the variance component was calculated from the variance of isolate aggressiveness found among screening locations and within each screening location. At maximum, three fields and seven samples per field were collected from each of the four locations where disease conditions were favorable.

Table 1. Collection information for each greenhouse screening isolate of Sclerotinia sclerotiorum

\begin{tabular}{|c|c|c|c|c|}
\hline Isolate number & Collaborator & Date & Location & Host bean class ${ }^{a}$ \\
\hline 1.1980 & J. Steadman & 1980 & Mitchell, NE & Great northern \\
\hline 2. NE 152 & J. Steadman & 1980 & Mitchell, NE & Great northern \\
\hline 3. ND 274 & K. Grafton & 1995 & Scottsbluff, NE & Great northern \\
\hline 4. NY 443 & P. Griffiths & 1989 & Orleans Co., NY & Snap bean \\
\hline 5. OR 455 & J. Myers & 1998 & Corvallis, OR & WM bean* \\
\hline 6. WA 456 & P. Miklas & 1996 & Quincy, WA & Newport navy \\
\hline 7. CO 467 & H. Schwartz & 1996 & Colorado Front Range & Pinto bean \\
\hline 8. WI 478 & K. Kmiecik & 2002 & Wisconsin & Snap bean \\
\hline 9. MI 482 & J. Kelly & 2003 & Montcalm, MI & Black bean \\
\hline 10. ID 483 & S. Singh & 2003 & Hazelton, ID & Various bean** \\
\hline
\end{tabular}

${ }^{\text {a }}$ Isolate was collected from $*=$ bean lines grown in the white mold monitor nursery and $* *=$ bean lines grown in a white mold fungicide trial. 
Inoculum preparation. Cultures of $S$. sclerotiorum used in characterization assays were reactivated from sclerotia by surface sterilization and plating on media. Once collected, the isolates were stored in petri plates lined with filter paper, then stored at $20^{\circ} \mathrm{F}$ or $-4^{\circ} \mathrm{C}$. Sclerotia were triple rinsed with (i) $50 \%$ Clorox bleach $/ 50 \%$ double-distilled (dd) $\mathrm{H}_{2} \mathrm{O}$ solution for $3 \mathrm{~min}$, (ii) $\mathrm{ddH}_{2} \mathrm{O}$ rinse for $3 \mathrm{~min}$, and (iii) final $\mathrm{ddH}_{2} \mathrm{O}$ rinse for $3 \mathrm{~min}$, then plated on water agar plates ( $16 \mathrm{~g}$ of Bacto agar per liter of $\mathrm{ddH}_{2} \mathrm{O}$ ), with four to five sclerotia of each isolate separated on each plate and stored on the bench top at room temperature for 5 to 6 days An 8-mm plug from a 5- or 6-day-old culture was transferred from the advancing margin of the mycelia onto a plate of Difco potato dextrose agar (PDA at $39 \mathrm{~g} /$ liter of $\mathrm{ddH}_{2} \mathrm{O}$ ).

MCGs. For the MCGs, an 8-mm plug was taken from approximately $1 \mathrm{~mm}$ behind the advancing margin of the mycelia and placed mycelia side down on a plate of Diana Sermons (DS) medium (10): malt extract broth at $40 \mathrm{~g} /$ liter (Sigma-Aldrich, St. Louis), $\mathrm{NaCl}$ at $20 \mathrm{~g} /$ liter, Bacto peptone at $5 \mathrm{~g} /$ liter (BD Diagnostic Systems, Sparks, MD), Bacto agar at $15 \mathrm{~g} /$ liter (BD Diagnostic Systems), McCormick's red food dye ( $80 \mu \mathrm{l} /$ liter) and McCormick's yellow food dye $(80 \mu \mathrm{l} /$ liter) (Hy-Vee Food Stores, Des Moines, IA), and 1 liter of $\mathrm{ddH}_{2} \mathrm{O}$. Isolates were grown on DS media plates for $48 \mathrm{~h}$ on the bench top at room temperature before use in an MCG test. To determine the MCGs, each possible pair of isolates was grown in a side-by-side pairing by placing an $8-\mathrm{mm}$ plug of an isolate from a DS culture or a blank control on a plate of DS medium, $2.5 \mathrm{~cm}$ apart. Each isolate pairing was duplicated. Each pairing was incubated on the bench top at room temperature for 9 days.

Mycelial incompatibility is a failure of different strains to grow together and form one colony and is characterized by the formation of dead cells (barrage line) and reduced growth between the two isolate colonies (22). If a barrage line of dead cells forms, isolates are incompatible and each isolate is unique. If isolates grow together, isolates are compatible and considered clonal. Each plate, including the duplicate of each pairing, was read at 3,6, and 9 days after transfer by three different observers. At the 9-day reading, typically one line of sclerotia formed in the middle of the culture plate where hyphae of the two isolates met in a compatible reaction. In an incompatible reaction, two lines of sclerotia formed on respective sides of the barrage line; these observations may have implications as a diagnostic aid. The results were recorded in a matrix: an incompatible reaction or a compatible reaction.

Screening isolate MCG experimental design. To determine clonality of greenhouse isolates, all 10 greenhouse isolates were paired in a matrix first. For each screening location, all of the field screening isolates were tested within a screening location (i.e., all Nebraska isolates collected from 2003 to 2005 were tested). If a greenhouse screening location belonged to one of the sites that also had field screening isolates, the greenhouse isolate was added to the isolates to test within-field variation. For example, all of the Nebraska isolates collected over the 3 years and Nebraska greenhouse screening isolate 152 were tested for pairwise compatibility within field (within site) MCGs. Representative isolates were then selected from each within-field MCG found. Every MCG formed by a single isolate was automatically included to represent that MCG. The representative MCG field isolates were then tested between field locations for clonality. Locations that only had a few representative isolates for between-site MCG isolate comparisons were tested among each other, then combined to test against fields with larger representative isolate groups. For example, the greenhouse isolate group only had three isolates that did not have a corresponding isolate collected from the field from the same location. Michigan only had eight representative isolates, and North Dakota had three. They were tested against each other then grouped together to test against other fields as the MI-ND-GH group. The same was true for the Oregon and Minnesota (OR-MN) and the Nebraska and Mexico (NE-MX) groups. A final experiment was conducted to verify that all isolates in the same MCG were compatible.
Producer isolate MCG experimental design. All isolates collected from the same producer field were paired with the representative MCG screening isolates for that same location.

Planting for greenhouse screening experiments. Seed were pregerminated by incubating in rolled-up, damp paper towels stored in plastic bread sacks. The sacks were incubated in a $27 \pm$ $1{ }^{\circ} \mathrm{C}$ incubator for $48 \mathrm{~h}$. The germinated seed were swollen from imbibed water and, in most cases, the radical had emerged. The soil mix for the greenhouse experiment was one-third peat moss, one-third sand-vermiculite (one-half each), and one-third top soil mix. The plants were fertilized with a solution of granular Peter's 20-20-20 NPK and water at $250 \mathrm{ppm}$ three times per week. The greenhouse temperatures were maintained at $20 \pm 1^{\circ} \mathrm{C}$ (night, $12 \mathrm{~h}$ ) and $26 \pm 1{ }^{\circ} \mathrm{C}$ (day, $12 \mathrm{~h}$ ). Greenhouse lights supplemented daylight to $12 \mathrm{~h}$ each day. Each bean seed was planted in a $15-\mathrm{cm}$ sterile clay pot and placed on a greenhouse bench according to the experimental design.

The straw test. Plants were inoculated below the fifth node, which was terminal for determinant lines, 21 days after the seed were planted, at the stage just preceding flowering. For inoculation, clear drinking straws were cut to $2.5 \mathrm{~cm}$ in length and sealed by melting the tip of one end of the straw with a flame and pinching with sterile forceps. The open end of the straw was pressed into the reverse side of a 2-day-old PDA culture of $S$. sclerotiorum mycelia twice, which filled the straw with two plugs. The stem of the bean plant was cut at $2.5 \mathrm{~cm}$ above the fourth node. The straw with fungal mycelium was then placed over the cut part of the stem. Plants were incubated in the greenhouse at $20 \pm 1^{\circ} \mathrm{C}$ night and $26 \pm 1{ }^{\circ} \mathrm{C}$ day temperatures for 8 days when they were rated using the Modified Petzoldt and Dickson scale (38). This rating scale is used for screening bean lines for white mold reaction: a rating of 1 to 3 is considered resistant (no disease symptoms or symptoms to the adjacent first node), 4 to 6 is considered intermediate (white mold symptoms beyond the adjacent node to the next node), and 7 to 9 is considered susceptible (white mold symptoms past the second node to plant death). Capillary trays were placed under pots for watering from the bottom to prevent washing off the inoculum.

Straw test experimental designs. Experiment 1. G122 was the host for inoculation with the 10 greenhouse screening isolates, evaluated for aggressiveness by the straw test. In all, 100 seeds of G122 were pregerminated and planted at the same time. Ten pots were grouped together into a block where each pot received 1 of the 10 isolates. The experimental design was a randomized complete block design with 10 treatments in each block. There were 10 blocks in each replication and 10 replications where a replication was a complete set of 10 blocks planted on the same day.

Experiment 2. Ten cultivars from a variety of seed classes (e.g., pinto, great northern, and kidney) with different levels of white mold resistance in Andean and Middle American gene pool backgrounds were inoculated with the 10 greenhouse screening isolates to evaluate separation of isolate and aggressiveness in the straw test. The 10 isolates of $S$. sclerotiorum were tested on the 10 cultivars, for a total of 100 cultivar-isolate treatment combinations, to determine the effect of genetic backgrounds of the seed classes on separation of isolate or MCG aggressiveness. The MCGs formed by the 10 greenhouse or laboratory screening isolates were also characterized by their aggressiveness on the 10 cultivars. Ten seeds of each cultivar were pregerminated and planted in separate pots at the same time. The experimental design was a randomized incomplete block with four treatments per block (four inoculated plants per watering tray), 25 blocks for every replication, and 11 replications for the experiment (every treatment was replicated 11 times).

Experiment 3. All 156 isolates (total greenhouse and field) were tested for aggressiveness on G122 using the straw test. The experimental design was a chain block $\alpha$ lattice of 16 experiments. The 156 isolates, plus 4 checks, were given a randomized isolate number and assigned to sets. Each week, 20 different isolates were tested, with 4 isolates per incomplete block and six complete replicates. Each isolate-G122 treatment was replicated a total of 12 
times. There were four inoculated plants per block (watering tray), and five blocks (trays) in every replication, for a total of 12 plants evaluated per isolate. Each isolate set was randomized and repeated at least 6 weeks apart.

Experiment 4. Each set of producer field isolates and the isolates representative of the screening isolate MCGs from the same location were tested for aggressiveness for that location. The experimental design for each producer location experiment was a randomized complete block design with 12 replications. There were three treatments per block but the number of blocks per replication was 8 for Nebraska and North Dakota, 9 for Colorado, and 12 for Washington.

Data analysis. Analysis of variance of mean straw test rating scores of the greenhouse screening of isolates of $S$. sclerotiorum and tests of significance were performed using SAS PROC GLM for mixed models (32) for all tests of aggressiveness.

\section{Results}

MCGs. The 3-, 6-, and 9-day post-isolate transfer data readings were summarized in a final data matrix (Table 2). After the isolates had interacted for 6 days, data readings were consistent for all three observers. The nine greenhouse screening isolates formed six MCGs identified as A to F. The control 1980, Nebraska, and Oregon isolates make up MCG A. The Wisconsin and New York isolates were compatible, and make up MCG B. The Colorado and North Dakota isolates make up MCG C. The Michigan, Idaho, and Washington isolates were incompatible with every other screening isolate, making them unique and each defining their own MCG; these are $\mathrm{D}, \mathrm{E}$, and $\mathrm{F}$, respectively (Table 3 ).

Within the 156 total isolates, 64 MCGs were found (Table 4). Of the 64 MCGs, 36 MCGs were composed of a single unique isolate, while 6 MCGs were composed of isolates collected from multiple locations. In each of the other 22 MCGs, a single MCG was composed of isolates from within a single screening site. Each of these MCGs represents clones from a single site (Fig. 1).

The nine greenhouse screening isolates are clones of at least one isolate found at a field screening location in the United States, except MCG E, that only had one member, the Idaho screening isolate. This isolate is unique in all respects, because it does not share any MCGs with another screening isolate or the entire group of 146 field isolates collected from across the United States, France, and Mexico (no field isolates were collected from Idaho; therefore, this field was not represented). MCG A and MCG B are widely distributed; these are clones of many different isolates from several different locations across the United States. Only isolates from Washington, Oregon, Minnesota, Michigan, and the North Dakota field were represented in the greenhouse MCGs.

When producer field isolates from Washington, Nebraska, North Dakota, and Colorado were compared with greenhouse and field screening isolates from the same location, high diversity was found in each location. For the 20 isolates collected from Colorado, six MCGS were identified; two MCGs were unique to the producer fields and four MCGs were compatible with screening isolates from the same location. In Nebraska, 10 producer field isolates were collected and four MCGs were found; one MCG was unique to the producer fields and three MCGs were compatible with screening isolates from the same location. Of the 21 North Dakota producer field isolates, 11 MCGs were identified; 9 MCGs were unique to producer fields while 2 MCGs were compatible with screening isolates from North Dakota. Finally, 22 isolates were collected from Washington and 13 MCGs were found; 10 MCGs were unique to the Washington producer fields and 3 MCGs were compatible with screening isolates from Washington (Fig. 2).

Separation of aggressiveness by greenhouse isolate and MCG on G122. There were significant differences within the aggressiveness ratings of 10 greenhouse isolates $(P=0.0003$; Fig. $3 \mathrm{~A})$ but there were no significant rating differences found due to blocking $(P=0.0914)$. The Idaho screening isolate 483 was the least aggressive isolate and was significantly different from all of the other isolates, except Oregon isolate 455. The New York 443 and Wisconsin 478 isolates were the most aggressive.

When the MCGs formed by the greenhouse screening isolates were compared, the differences between MCGs were highly significant with regard to aggressiveness $(P \leq 0.0001)$ (Fig. 3B). However, the isolates within the MCGs were not significantly different in aggressiveness $(P=0.2468)$. MCG $\mathrm{E}$, formed by the unique isolate ID 483, was significantly less aggressive than any of the other MCGs.

Separation of greenhouse isolates and MCG aggressiveness using 10 host bean lines. The 10 isolates were significantly different from each other $(P<0.0001$; Fig. 3A). However, no isolatecultivar interaction was found $(P=0.2976)$. The Idaho screening isolate 483 was the least aggressive isolate and was significantly different from all other isolates. Also, the New York and Wisconsin isolates were significantly more aggressive than the other greenhouse isolates. When this straw test was compared with the 2006 test in which the 10 greenhouse screening isolates were tested on host G122, the New York and Wisconsin isolates were consistently more aggressive than other isolates and the Idaho isolate was consistently less aggressive. Although the rank of the remaining isolates differed between the two tests, they were not significantly different in aggressiveness from each other because there was no isolate-cultivar interaction; therefore, some rank change was not important. There also were significant differences found between the resistance of the host cultivars when the aggressiveness of the isolates and isolates within an MCG were tested $(P<0.0001)$.

When the MCGs formed by the greenhouse screening isolates were compared, the differences in aggressiveness were highly significant $(P \leq 0.0001$; Fig. 3B). As in the previous test, the isolates

Table 3. Six mycelial compatibility groups (MCGs) formed by the greenhouse screening isolates of Sclerotinia sclerotiorum

\begin{tabular}{lll}
\hline MCG & Isolate number & \multicolumn{1}{c}{ Isolate location } \\
\hline A & $1980,152,455$ & Control, Nebraska, Oregon \\
B & 478,443 & Wisconsin, New York \\
C & 467,274 & Colorado, North Dakota \\
D & 482 & Michigan \\
E & 483 & Idaho \\
F & 456 & Washington \\
\hline
\end{tabular}

Table 2. Summary of the mycelial compatibility groupings formed by the 10 greenhouse isolates of Sclerotinia sclerotiorum ${ }^{\mathrm{a}}$

\begin{tabular}{|c|c|c|c|c|c|c|c|c|c|c|}
\hline Isolate & 1980 & 152 & 274 & 443 & 455 & 456 & 467 & 478 & 482 & 483 \\
\hline 1980 & $\mathrm{O}$ & $\underline{\mathbf{O}}$ & $\mathrm{X}$ & $\mathrm{X}$ & $\underline{\mathbf{O}}$ & $X$ & $\mathrm{X}$ & $\mathrm{X}$ & $\mathrm{X}$ & $X$ \\
\hline NE 152 & & $\overline{\mathrm{O}}$ & $\mathrm{X}$ & $\mathrm{X}$ & $\underline{\overline{\mathbf{O}}}$ & $X$ & $X$ & $\mathrm{X}$ & $X$ & $X$ \\
\hline ND 274 & & & $\mathrm{O}$ & $\mathrm{X}$ & $\bar{X}$ & $\mathrm{X}$ & O & $\mathrm{X}$ & $\mathrm{X}$ & $\mathrm{X}$ \\
\hline NY 443 & & & & $\mathrm{O}$ & $X$ & $\mathrm{X}$ & $\bar{X}$ & $\underline{\mathbf{O}}$ & $\mathrm{X}$ & $X$ \\
\hline OR 455 & & & & & $\mathrm{O}$ & $\mathrm{X}$ & $X$ & $\bar{X}$ & $X$ & $X$ \\
\hline WA 456 & & & & & & $\mathrm{O}$ & $\mathrm{X}$ & $\mathrm{X}$ & $\mathrm{X}$ & $\mathrm{X}$ \\
\hline CO 467 & & & & & & & $\mathrm{O}$ & $\mathrm{X}$ & $\mathrm{X}$ & $\mathrm{X}$ \\
\hline WI 478 & & & & & & & & $\mathrm{O}$ & $\mathrm{X}$ & $\mathrm{X}$ \\
\hline MI 482 & & & & & & & & & $\mathrm{O}$ & $\mathrm{X}$ \\
\hline ID 483 & & & & & & & & & & $\mathrm{O}$ \\
\hline
\end{tabular}

a $\mathrm{X}=$ incompatible reaction, $\mathrm{O}=$ isolate compatible with itself, and $\underline{\mathrm{O}}=$ isolate compatible with another greenhouse isolate. 
Table 4. Collection information for the Sclerotinia sclerotiorum field and greenhouse screening isolates which form the 64 mycelial compatibility groupings (MCGs)

\begin{tabular}{|c|c|c|c|c|}
\hline MCG & Isolate & Location & Year & Host cultivar-rep \\
\hline \multirow[t]{5}{*}{1} & 603 & France & 2004 & Bunsi-Rep 2 \\
\hline & 573 & Nebraska & 2004 & G122-Rep 1 \\
\hline & 574 & Nebraska & 2004 & G122-Rep 2 \\
\hline & 575 & Nebraska & 2004 & G122-Rep 3 \\
\hline & 576 & Nebraska & 2004 & Beryl-Rep 1 \\
\hline \multirow[t]{6}{*}{2} & 589 & Oregon & 2004 & Beryl-Rep 3 \\
\hline & 457 & Washington & 2003 & Beryl-Rep 1 \\
\hline & 566 & Washington & 2004 & Bunsi-Rep 1 \\
\hline & 567 & Washington & 2004 & Bunsi-Rep 2 \\
\hline & 647 & Washington & 2005 & G122-Rep 1 \\
\hline & 456 & Washington & 1996 & GH isolate \\
\hline \multirow[t]{5}{*}{3} & 584 & Oregon & 2004 & G122-Rep 1 \\
\hline & 446 & Michigan & 2003 & Beryl-Rep 1 \\
\hline & 448 & Michigan & 2003 & Beryl-Rep 3 \\
\hline & 449 & Michigan & 2003 & Bunsi-Rep 1 \\
\hline & 662 & Michigan & 2005 & Bunsi-Rep1 \\
\hline \multirow[t]{11}{*}{4} & 444 & Minnesota & 2003 & G122-Rep 1 \\
\hline & 445 & Minnesota & 2003 & Beryl-Rep 1 \\
\hline & 562 & Minnesota & 2004 & Beryl-Rep 2 \\
\hline & 565 & Washington & 2004 & Beryl-Rep 2 \\
\hline & 569 & Washington & 2004 & G122-Rep 2 \\
\hline & 585 & Oregon & 2004 & G122-Rep 2 \\
\hline & 588 & Oregon & 2004 & Beryl-Rep 2 \\
\hline & 453 & Michigan & 2003 & G122-Rep 2 \\
\hline & 455 & Oregon & 1998 & GH isolate \\
\hline & 152 & Nebraska & 1980 & GH isolate \\
\hline & 1980 & Control isolate & 1980 & GH isolate \\
\hline \multirow{8}{*}{5} & 473 & Oregon & 2003 & Bunsi-Rep 2 \\
\hline & 476 & Oregon & 2003 & G122-Rep 2 \\
\hline & 587 & Oregon & 2004 & Beryl-Rep 1 \\
\hline & 590 & Oregon & 2004 & Bunsi-Rep 1 \\
\hline & 592 & Oregon & 2004 & Bunsi-Rep 3 \\
\hline & 463 & Washington & 2003 & G122-Rep 1 \\
\hline & 651 & Washington & 2005 & Beryl-Rep 3 \\
\hline & 447 & Michigan & 2003 & Beryl-Rep 2 \\
\hline \multirow[t]{8}{*}{5} & 450 & Michigan & 2003 & Bunsi-Rep 2 \\
\hline & 452 & Michigan & 2003 & G122-Rep 1 \\
\hline & 611 & Michigan & 2004 & Beryl \\
\hline & 665 & Michigan & 2005 & G122-Rep 2 \\
\hline & 669 & Michigan & 2005 & Bunsi-Rep 3 \\
\hline & 654 & North Dakota & 2005 & G122-Rep 1 \\
\hline & 443 & New York & 1989 & GH isolate \\
\hline & 478 & Wisconsin & 2002 & GH isolate \\
\hline \multirow{2}{*}{6} & 577 & Nebraska & 2004 & Beryl-Rep 2 \\
\hline & 643 & Nebraska & 2005 & G122-Rep 1 \\
\hline 7 & 570 & Nebraska & 2004 & Bunsi-Rep 1 \\
\hline 8 & 571 & Nebraska & 2004 & Bunsi-Rep 2 \\
\hline 9 & 642 & Nebraska & 2005 & G122-Rep 2 \\
\hline \multirow[t]{2}{*}{10} & 469 & Oregon & 2003 & Beryl-Rep 1 \\
\hline & 477 & Oregon & 2003 & G122-Rep 3 \\
\hline 11 & 472 & Oregon & 2003 & Bunsi-Rep 1 \\
\hline 12 & 474 & Oregon & 2003 & Bunsi-Rep 3 \\
\hline 13 & 483 & Idaho & 2003 & GH isolate \\
\hline 14 & 586 & Oregon & 2004 & G122-Rep 3 \\
\hline 15 & 591 & Oregon & 2004 & Bunsi-Rep 2 \\
\hline \multirow[t]{3}{*}{16} & 451 & Michigan & 2003 & Bunsi-Rep 3 \\
\hline & 454 & Michigan & 2003 & G122-Rep 3 \\
\hline & 664 & Michigan & 2005 & Bunsi-Rep 2 \\
\hline \multirow[t]{2}{*}{17} & 661 & Michigan & 2005 & G122-Rep 1 \\
\hline & 668 & Michigan & 2005 & Beryl-Rep 3 \\
\hline 18 & 482 & Michigan & 2003 & GH isolate \\
\hline & 663 & Michigan & 2005 & Beryl-Rep 1 \\
\hline 19 & 666 & Michigan & 2005 & Beryl-Rep 2 \\
\hline 20 & 667 & Michigan & 2005 & G122-Rep 3 \\
\hline 21 & 594 & California & 2004 & Bunsi-Rep 2 \\
\hline & 678 & California & 2005 & G122-Rep 3 \\
\hline 22 & 598 & California & 2004 & G122-Rep 3 \\
\hline & 601 & California & 2004 & Beryl-Rep 3 \\
\hline 23 & 600 & California & 2004 & Beryl-Rep 2 \\
\hline & 679 & California & 2005 & Bunsi-Rep 1 \\
\hline 24 & 673 & California & 2005 & Beryl-Rep 1 \\
\hline & & & $(\mathrm{cor}$ & d in next column) \\
\hline
\end{tabular}

Table 4. (continued from previous column)

\begin{tabular}{|c|c|c|c|c|}
\hline MCG & Isolate & Location & Year & Host cultivar-rep \\
\hline & 680 & California & 2005 & Bunsi-Rep 2 \\
\hline \multirow[t]{3}{*}{25} & 596 & California & 2004 & G122-Rep 1 \\
\hline & 599 & California & 2004 & Beryl-Rep 1 \\
\hline & 676 & California & 2005 & G122-Rep 1 \\
\hline 26 & 681 & California & 2005 & Bunsi-Rep 3 \\
\hline 27 & 593 & California & 2004 & Bunsi-Rep 1 \\
\hline 28 & 595 & California & 2004 & Bunsi-Rep 3 \\
\hline 29 & 597 & California & 2004 & G122-Rep 2 \\
\hline 30 & 674 & California & 2005 & Beryl-Rep 2 \\
\hline 31 & 675 & California & 2005 & Beryl-Rep 3 \\
\hline 32 & 677 & California & 2005 & G122-Rep 2 \\
\hline \multirow[t]{3}{*}{33} & 605 & France & 2004 & Beryl-Rep 1 \\
\hline & 606 & France & 2004 & Beryl-Rep 2 \\
\hline & 607 & France & 2004 & Beryl-Rep 3 \\
\hline \multirow[t]{2}{*}{34} & 608 & France & 2004 & G122-Rep 1 \\
\hline & 684 & France & 2005 & Bunsi-Rep 3 \\
\hline \multirow[t]{4}{*}{35} & 686 & France & 2005 & Beryl-Rep 2 \\
\hline & 687 & France & 2005 & Beryl-Rep 3 \\
\hline & 689 & France & 2005 & G122-Rep 2 \\
\hline & 690 & France & 2005 & G122-Rep 3 \\
\hline 36 & 602 & France & 2004 & Bunsi-Rep 1 \\
\hline 37 & 604 & France & 2004 & Bunsi-Rep 3 \\
\hline 38 & 609 & France & 2004 & G122-Rep 2 \\
\hline 39 & 610 & France & 2004 & G122-Rep 3 \\
\hline 40 & 682 & France & 2005 & Bunsi-Rep 1 \\
\hline 41 & 683 & France & 2005 & Bunsi-Rep 2 \\
\hline 42 & 685 & France & 2005 & Beryl-Rep 1 \\
\hline 43 & 688 & France & 2005 & G122-Rep 1 \\
\hline \multirow[t]{6}{*}{44} & 572 & Nebraska & 2004 & Bunsi-Rep 3 \\
\hline & 578 & Nebraska & 2004 & Beryl-Rep 3 \\
\hline & 639 & Nebraska & 2005 & G122-Rep 3 \\
\hline & 640 & Nebraska & 2005 & Beryl-Rep 3 \\
\hline & 641 & Nebraska & 2005 & Beryl-Rep 2 \\
\hline & 644 & Nebraska & 2005 & Beryl-Rep 1 \\
\hline \multirow[t]{3}{*}{45} & 274 & North Dakota & 1995 & GH isolate \\
\hline & 467 & Colorado & 1996 & GH isolate \\
\hline & 660 & North Dakota & 2005 & Beryl-Rep 3 \\
\hline \multirow[t]{5}{*}{46} & 655 & North Dakota & 2005 & Bunsi-Rep 1 \\
\hline & 656 & North Dakota & 2005 & Beryl-Rep 1 \\
\hline & 657 & North Dakota & 2005 & G122-Rep 2 \\
\hline & 658 & North Dakota & 2005 & Beryl-Rep 2 \\
\hline & 659 & North Dakota & 2005 & G122-Rep 3 \\
\hline \multirow[t]{2}{*}{47} & 615 & Mexico & 2004 & Bunsi-Rep 3 \\
\hline & 632 & Mexico & 2004 & Bunsi-Rep 3 \\
\hline \multirow[t]{2}{*}{48} & 616 & Mexico & 2004 & Beryl-Rep 3 \\
\hline & 624 & Mexico & 2004 & G122-Rep 1 \\
\hline \multirow[t]{9}{*}{49} & 617 & Mexico & 2004 & G122-Rep 3 \\
\hline & 618 & Mexico & 2004 & Bunsi-Rep 2 \\
\hline & 619 & Mexico & 2004 & Beryl-Rep 2 \\
\hline & 622 & Mexico & 2004 & Beryl-Rep 1 \\
\hline & 623 & Mexico & 2004 & G122-Rep 1 \\
\hline & 625 & Mexico & 2004 & Beryl-Rep 1 \\
\hline & 626 & Mexico & 2004 & Bunsi-Rep 1 \\
\hline & 627 & Mexico & 2004 & G122-Rep 2 \\
\hline & 628 & Mexico & 2004 & Beryl-Rep 2 \\
\hline 50 & 620 & Mexico & 2004 & G122-Rep 2 \\
\hline & 630 & Mexico & 2004 & G122-Rep 3 \\
\hline & 631 & Mexico & 2004 & Beryl-Rep 3 \\
\hline 51 & 621 & Mexico & 2004 & Bunsi-Rep 1 \\
\hline 52 & 629 & Mexico & 2004 & Bunsi-Rep 2 \\
\hline 53 & 459 & Washington & 2003 & Beryl-Rep 3 \\
\hline & 465 & Washington & 2003 & G122-Rep 3 \\
\hline & 568 & Washington & 2004 & G122-Rep 1 \\
\hline & 645 & Washington & 2005 & Beryl-Rep 1 \\
\hline & 648 & Washington & 2005 & Beryl-Rep 2 \\
\hline & 653 & Washington & 2005 & G122-Rep 3 \\
\hline 54 & 458 & Washington & 2003 & Beryl-Rep 2 \\
\hline 55 & 460 & Washington & 2003 & Bunsi-Rep 1 \\
\hline 56 & 461 & Washington & 2003 & Bunsi-Rep 2 \\
\hline 57 & 462 & Washington & 2003 & Bunsi-Rep 3 \\
\hline 58 & 464 & Washington & 2003 & G122-Rep 2 \\
\hline 59 & 564 & Washington & 2004 & Beryl-Rep 1 \\
\hline 60 & 646 & Washington & 2005 & Bunsi-Rep 1 \\
\hline
\end{tabular}


Table 4. (continued from preceding page)

\begin{tabular}{lclcc}
\hline MCG & Isolate & Location & Year & Host cultivar-rep \\
\hline 61 & 649 & Washington & 2005 & Bunsi-Rep 2 \\
62 & 650 & Washington & 2005 & G122-Rep 2 \\
63 & 652 & Washington & 2005 & Bunsi-Rep 3 \\
64 & 555 & Minnesota & 2004 & Bunsi-Rep 1 \\
& 556 & Minnesota & 2004 & Bunsi-Rep 2 \\
& 557 & Minnesota & 2004 & Bunsi-Rep 3 \\
& 558 & Minnesota & 2004 & G122-Rep 1 \\
& 559 & Minnesota & 2004 & G122-Rep 2 \\
& 560 & Minnesota & 2004 & G122-Rep 3 \\
& 561 & Minnesota & 2004 & Beryl-Rep 1 \\
& 563 & Minnesota & 2004 & Beryl-Rep 3 \\
\hline
\end{tabular}

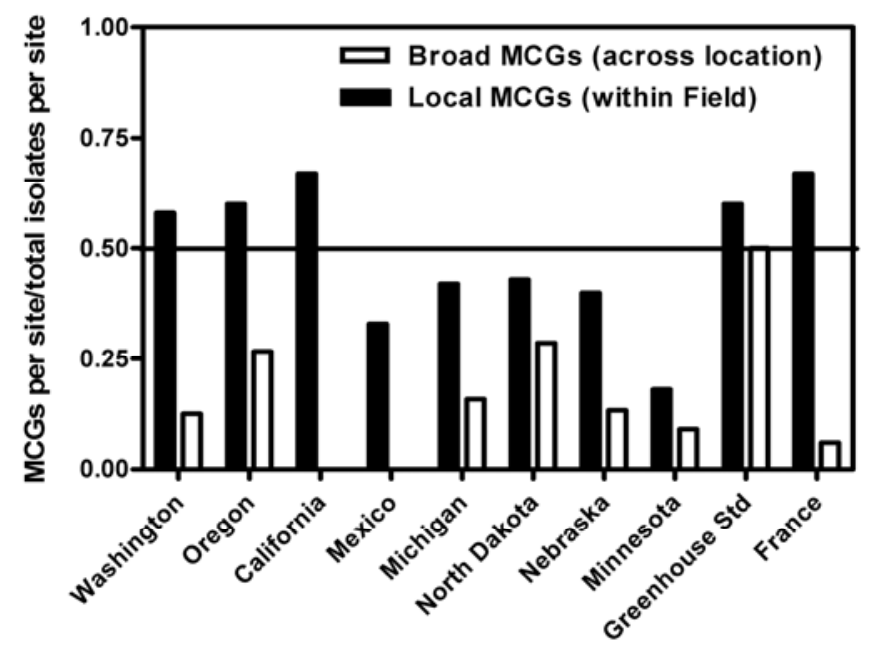

Screening isolate location

Fig. 1. Proportion of mycelial compatibility groups (MCGs) identified across screening locations and proportion of MCGs found within each screening location.



Fig. 2. Proportion of producer field mycelial compatibility groups (MCGs) to total isolates collected, proportion of unique producer field MCGs, and proportion of MCGs compatible with screening isolates per location.

within MCGs were not significantly different from each other $(P=$ $0.1597)$ in aggressiveness; thus, differences found in isolate aggressiveness may be associated with the MCGs. MCG E, formed by the unique isolate ID 483, was significantly different from any of the other MCGs. These results are consistent with results from the use of the single host G122. When the aggressiveness of the MCGs from the two tests was compared, the most aggressive MCG continued to be MCG B, while the least aggressive was MCG E. Again, MCGs A, $\mathrm{C}, \mathrm{D}$, and $\mathrm{F}$ were not significantly different in aggressiveness whether the host was G122 or the 10 different cultivars.

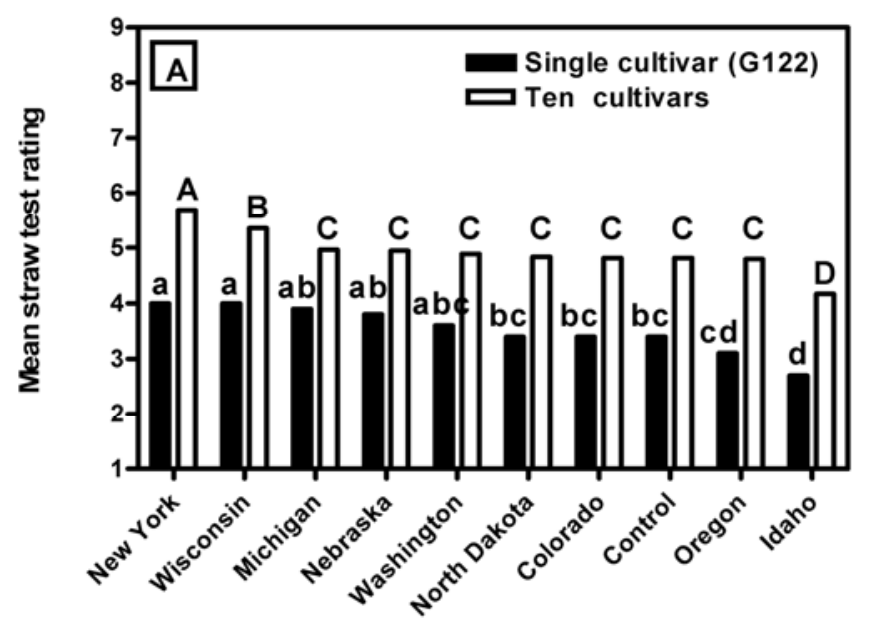

Standard greenhouse screening isolates

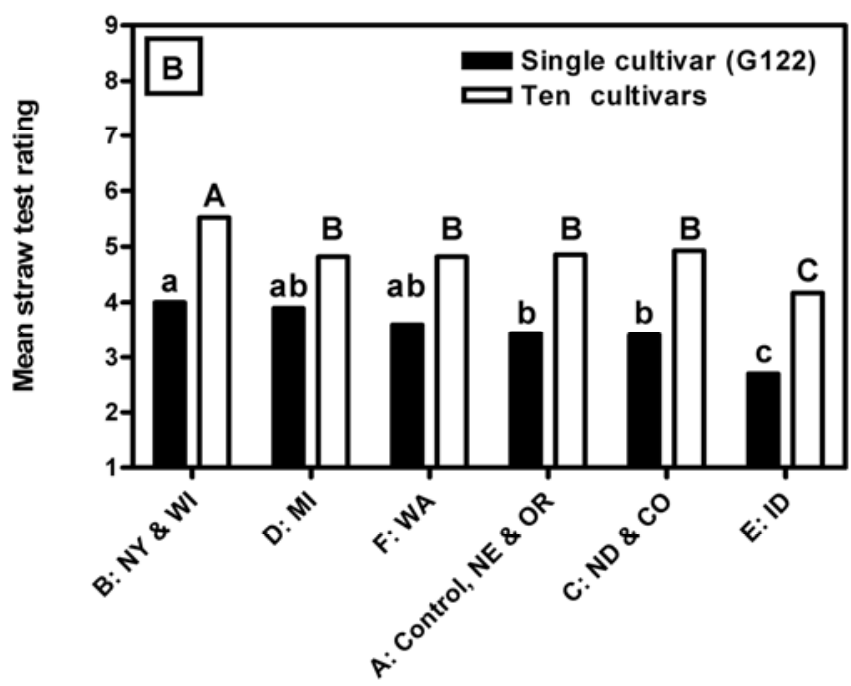

Standard greenhouse MCGs

Fig. 3. A, Mean straw test (ST) ratings for the 10 greenhouse screening isolates tested on ' $G 122$ ' and 10 cultivars with differing white mold resistance backgrounds. $B$, Mean ST ratings for the six greenhouse screening isolate MCGs tested on G122 and 10 cultivars with differing white mold resistance backgrounds.

Aggressiveness of the greenhouse and field screening isolates. Highly significant aggressiveness differences were found among the 156 isolates $(P<0.0001)$. When the isolates were grouped into their respective MCGs and the straw test means were analyzed, highly significant differences were again found between the MCGs $(P<0.0001)$. However, the isolates within the MCGs were not significantly different $(P=0.4408)$. MCG 9 had the highest mean straw test rating (most aggressive) and was significantly different from all other MCGs, with a rating of 7.50. MCG 9 was composed of only one unique Nebraska field isolate, isolate 642. MCG 15 had the lowest mean straw test rating (least aggressive) with a mean rating of 2.92. MCG 15 is the unique Oregon isolate 591. It was not significantly different in aggressiveness from MCG 25 (California 596, California 599, and California 676) and MCG 12 (unique Oregon isolate 474).

When isolates from each location-California, France, Mexico, Michigan, Minnesota, North Dakota, Nebraska, Oregon, Washington, and the greenhouse screening isolates classified as a collective groupwere analyzed by the straw test rating, highly significant differences were found between locations $(P<0.0001)$ (Fig. 4) and among the isolates within each location $(P<0.0001)$ (data not shown). The Minnesota isolates were significantly more aggressive than the isolates from the other locations, whereas the California isolates were significantly less aggressive than those from the rest of the locations. 
The mean straw test isolate rating of the year of collection (2003, 2004, and 2005) and the host cultivar (G122, ICA-Bunsi, and Beryl) were also compared. The ratings of isolates were not significantly different across years of collection $(P=0.1075)$. At a $10 \%$ significance level, differences were detected among the host source $(P=0.0603)$, and the most susceptible host, Beryl, was associated with the isolates with the highest aggressiveness.

Among the producer field isolates, significant differences were found between MCGs identified in Nebraska, Colorado, North Dakota, and Washington $(P=0.0002,0.0001,0.0034$, and 0.0472, respectively). Isolates were not significantly different within MCGs for Nebraska $(P=0.5299)$, North Dakota $(P=0.1003)$, and Washington $(P=0.5390)$. Slight differences were detected within MCGs for Colorado $(P=0.0205)$. The distribution of field screening and producer isolate MCGs over the range of aggressiveness (1-to-9 straw test rating) is illustrated in Figure 5.

\section{Discussion}

High genetic and phenotypic diversity was found among the greenhouse and field screening isolates from the major bean-production areas in the United States and locations in Mexico and France. Populations of S. sclerotiorum collected from North America have been reported as predominately clonal $(9,19,25)$. Genotypic and phenotypic uniformity of $S$. sclerotiorum isolates collected from Canada and Norway was also reported (20). Of the 156 total isolates, 64 MCGs were identified. Of those 64 MCGs, 36 were composed of a single unique isolate. Only six MCGs were sampled frequently across the nine screening locations.

Most population studies support a predominately clonal mode of evolution for S. sclerotiorum; however, occasional recombination, genetic exchange, and mutation can occur $(6,9,17,18)$. Because $S$. sclerotiorum is homothallic, it is not thought to readily outcross. Diseases caused by $S$. sclerotiorum are nearly all ascospore initiated (1). Because field screening plots have high populations of $S$. sclerotiorum due to the management of plots to promote disease annually, a higher threshold of white mold can be found in test plots than in grower fields each year, which can increase the frequency of infection during a growing season. Thus, mutation rather than sexual recombination may be a more logical explanation for genetic variation. Although there is low incidence of $S$. sclerotiorum being transmitted in healthy seed (34), introduction of new pathotypes by movement of seed is a possibility.

There is clear evidence for differences in aggressiveness between individual dry bean isolates and isolate MCGs collected from the major bean production areas in the United States and testing sites in Mexico and France. These results differ from previous studies such as that of Durman et al. (11), where isolates from

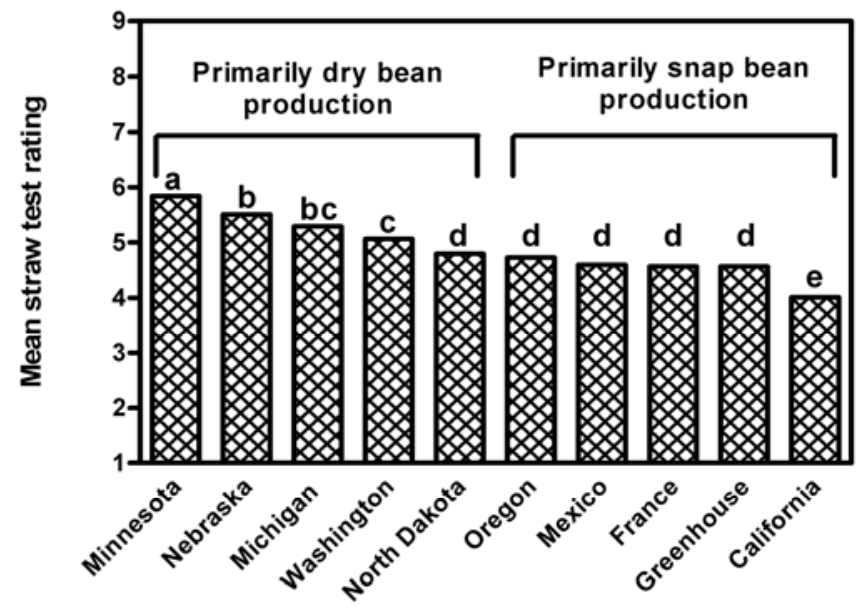

Location

Fig. 4. Mean straw test ratings of the isolates collected from each field location and the greenhouse collection. three host crops were compared and no differences in aggressiveness among MCGs were found. All isolates of that study were collected from fields within one province in Argentina. Bolton et al. (5) suggested that the low variation in aggressiveness among isolates from agricultural areas reported in some studies may result from only comparing isolates that were not collected from widely separated geographical regions. The reason for the variation in aggressiveness that we found could be continuously changing environments where the coexistence of several MCGs would be favored over a more clonal population $(11,19)$ that would be reflected in the identification of different phenotypes. In a study of potato isolates from the Washington Basin, high genetic diversity was found but no differences in aggressiveness were detected (2). One explanation could be that the isolates were collected only in the Columbia Basin. There also is a possibility that, in this study, the screening assay using colonized blossoms attached to potato plants to test for aggressiveness was not sensitive enough to detect differences between MCGs. In contrast, our bean isolate study deployed a standardized test that has been used extensively for screening for resistance in dry bean for the past decade. In both previously discussed cases, a lack of $S$. sclerotiorum aggressiveness was reported on tests using a single host and multiple hosts.

The nine greenhouse screening isolates were compared to determine their role in the variable disease responses found between greenhouse screening locations $(30,37)$. The results of our study indicate that not only is this group of isolates genetically diverse but aggressiveness is also significantly different. All the standard screening isolates were inoculated onto bean hosts using the same greenhouse technique (the straw test) and the same disease severity evaluation across locations, thus eliminating procedural differences. Significant variation was found between the nine greenhouse screening isolates, and there was a relationship between the aggressiveness and MCGs. This variation is likely to contribute to inconsistent greenhouse screening results across locations.

The variability found in and among the field screening locations reflected the variability found in the producer fields sampled in Nebraska, Washington, North Dakota, and Colorado. Colorado and Nebraska producer fields shared the same trend and many of the MCGs found in the producer fields were compatible, or clonal with the screening MCGs from the same location. Washington and North Dakota producer fields had more unique MCGs within each location but some of the MCGs identified were compatible with the screening field MCGs. The distribution of isolate aggressiveness for the field screening and producer field isolates ranged from a resistant reaction to near plant death on G122. The producer isolates mirrored the distribution of the screening field isolates, where the highest frequency of MCGs had a straw test rating of 4.00 to 4.50 for screening and producer field isolates. This level of aggres-

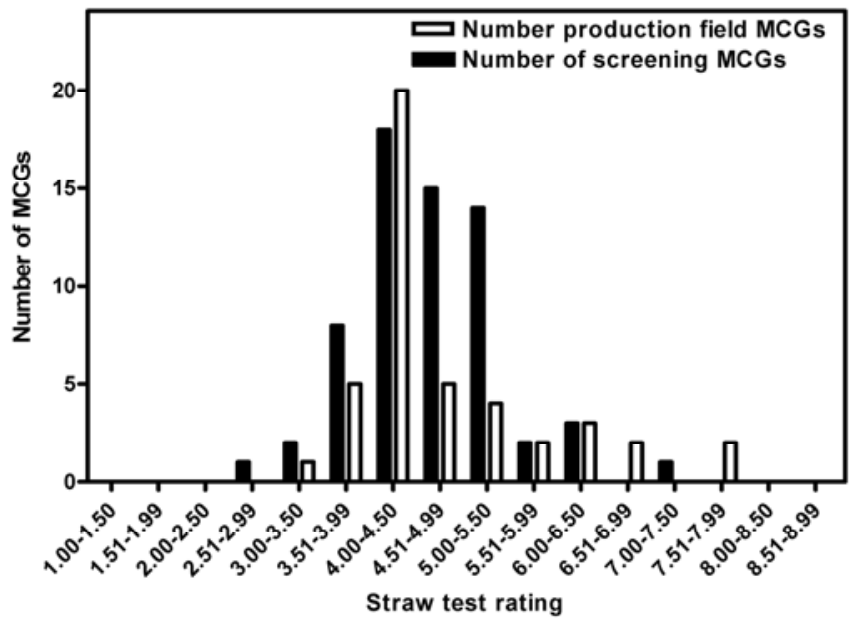

Fig. 5. Number of field screening and producer mycelial compatibility groups in straw test rating increment. 
siveness results in a partial resistance phenotype on G122 but would be a susceptible reaction on bean cultivars grown in any area of the United States. There was little separation of aggressiveness among MCGs when a susceptible cultivar was used as the host.

Within the clones of dry and green bean screening and grower field isolates, it was rare to find differences in aggressiveness between isolates. This could account for the lack of differences in isolate aggressiveness in S. sclerotiorum in locations where isolates were predominately clonal.

The control isolate 1980 and the Nebraska isolate 152 originated from the same source but were maintained as separate isolates for over 20 years. All isolates, including 1980 and 152, were never transferred from nutrient-rich media more than three times without being reisolated from infected plants to maintain isolate aggressiveness. The fact that they remain clones (MCG A) supports the findings of Kohli et al. (19) and Kull (25) that genetic control of an MCG is stable after serial transferring and possibly through successive sexual generations; thus, MCGs can and do persist from year to year $(11,14)$.

Kull et al. (26) recommended adapting a standard greenhouse screening method to lessen variability when searching for resistance to S. sclerotiorum; however, the aggressiveness of pathogen isolates also needs to be considered for reducing disease reaction variation between sites. If identification of low levels of resistance is a goal, less-aggressive isolates should be used. Similarly, highly aggressive isolates would be needed to identify higher resistance levels. Using the variability found in field environments and in greenhouse screening, isolates also can be beneficial for selecting broadly resistant bean lines. Selecting isolates for screening from within an MCG with defined aggressiveness may produce more consistent results in evaluating white mold disease resistance in greenhouse screening while using broadly dispersed clones.

\section{Acknowledgments}

We thank J. Behn, L. Sutton, and K. Powers for their most appreciated help in this endeavor; and P. Miklas, J. Kelly, H. Schwartz, J. Myers, C. Kurowski, R. Mainz, K. Grafton, K. Kmiecik, P. Griffiths, S. Singh, R. Felix, and A. Oppelaar for the field $S$. sclerotiorum isolate collections.

\section{Literature Cited}

1. Abawi, G. S., and Grogan, R. G. 1979. Epidemiology of diseases caused by Sclerotinia species. Phytopathology 69:899-904.

2. Atallah, Z. K., Larget, B., Chen, X., and Johnson, D. A. 2004. High genetic diversity, phenotypic uniformity, and evidence of outcrossing in Sclerotinia sclerotiorum in the Columbia Basin of Washington State. Phytopathology 94:737-742.

3. Bardin, S. D., and Huang, H. C. 2001. Research on biology and control of Sclerotinia diseases in Canada. Can. J. Plant Pathol. 23:88-98.

4. Boland, G. J., and Hall, R. 1994. Index of plant hosts of Sclerotinia sclerotiorum. Can. J. Plant Pathol. 16:93-108.

5. Bolton, M. D., Thomma, B. P. H. J., and Nelson, B. D. 2006. Sclerotinia sclerotiorum (Lib.) de Bary: biology and molecular traits of a cosmopolitan pathogen. Mol. Plant Pathol. 7:1-16.

6. Carbone, I., Anderson, J. B., and Kohn, L. M. 1999. Patterns of descent in clonal lineages and their multilocus fingerprints are resolved with combined gene genealogies. Evolution 53:11-21

7. Carpenter, M. A., Frampton, D., and Stewart, A. 1999. Genetic variation in New Zealand population of the plant pathogen Sclerotinia sclerotiorum. N.Z. J. Crop Hortic. Sci. 27:13-21.

8. Carson, M. L., Goodman, M. M., and Williamson, S. M. 2002.Variation in aggressiveness among isolates of Cercospora from maize as a potential cause of genotype-environment interaction in gray leaf spot trials. Plant Dis. $86: 1089-1093$

9. Cubeta, M. A., Cody, B. R., Kohli, Y., and Kohn, L. M. 1997. Clonality in Sclerotinia sclerotiorum in infected cabbage in eastern North Carolina. Phytopathology 87:1000-1004.

10. Cubeta, M. A., Sermons, D. N., and Cody, B. R. 2001. Mycelial interactions of Sclerotinia minor. (Abstr.) Phytopathology 91:S19.

11. Durman, S. B., Menendez, A. B., and Godeas, A. M. 2003. Mycelial compatibility groups in Buenos Aires field populations of Sclerotinia sclerotiorum (Sclerotiniaceae). Aust. J. Bot. 51:421-427.

12. Ekins, M. G., Aitken, E. A. B., and Goutler, K. C. 2007. Aggressiveness among isolates of Sclerotinia sclerotiorum from sunflower. Aust. Plant Pathol. 36:580-586.
13. Ford, E. J., Miller, R. V., Gray, H., and Sherwood, J. E. 1995. Heterokaryon formation and vegetative compatibility in Sclerotinia sclerotiorum. Mycol. Res. 99:241-247.

14. Hambelton, S., Walker, C., and Kohn L. M. 2002. Clonal lineages of Sclerotinia sclerotiorum previously known from other crop predominate in 1999-2000 samples from Ontario and Quebec soybean. Can. J. Plant Pathol. 24:309-315.

15. Hartman, G. L., Sinclair, J. B., and Rupe, J. C. 1999. Pages 46-48 in: Compendium of Soybean Diseases, 4th ed. American Phytopathological Society. St. Paul, MN.

16. Jochua, C., Amane, M. I. V., Steadman, J. R., Xue, X., and Eskridge, K. M. 2008. Virulence diversity of the dry bean rust pathogen within and among individual bean fields and development of sampling strategies. Plant Dis. 92:401-408.

17. Kohli, Y., Brunner, L. J., Yoell, H., Milgroom, M. G., Anderson, J. B., Morrall, R. A. A., and Kohn, L. M. 1995. Clonal dispersal and spatial mixing in populations of that plant pathogenic fungus Sclerotinia sclerotiorum. Mol. Ecol. 4:69-77.

18. Kohli, Y., Kohn, L. M. 1998. Random association among alleles in clonal populations of Sclerotinia sclerotiorum. Fungal Genet. Biol. 23:139-149.

19. Kohli, Y., Morrall, R. A. A., Anderson, J. B., and Kohn, L. M. 1992. Local and trans-Canadian clonal distribution of Sclerotinia sclerotiorum on canola. Phytopathology 82:875-880.

20. Kohn, L. M. 1995. The clonal dynamic in wild and agricultural plant-pathogen populations. Can. J. Bot. (Suppl. 1) 73:S1231-S1240.

21. Kohn, L. M., Carbone, I., and Anderson, J. B. 1990. Mycelial interactions in Sclerotinia sclerotiorum. Exp. Mycol. 14:255-267.

22. Kohn, L. M., Stasovski, E., Carbone, I., Royer, J., and Anderson, J. B. 1991. Mycelial compatibility and molecular markers identify genetic variability in field populations of Sclerotinia sclerotiorum. Phytopathology 81:480-485

23. Kolkman, J. M., and Kelly, J. D. 2002. Agronomic traits affecting resistance to white mold in dry bean. Crop Sci. 42:693-699.

24. Kull, L. S., Pedersen, W. P., and Hartman, G. L. 2001. Clonality and aggressiveness of Sclerotinia sclerotiorum. Pages 23-24 in: Proc. XI Int. Sclerotinia Workshop, York, UK.

25. Kull, L. S., Pedersen, W. L., Palmquist, D., and Hartman, G. L. 2004 Mycelial compatibility grouping and aggressiveness of Sclerotinia sclerotiorum. Plant Dis. 88:325-332.

26. Kull, L. S., Vuong, T. D., Powers, K. S., Eskridge, K. M., Steadman, J. R., and Hartman, G. L. 2003. Evaluation of three resistance screening methods using six Sclerotinia sclerotiorum isolates and three entries of each soybean and dry bean. Plant Dis. 87:1471-1476.

27. Lamey, H. A., Zollinger, R. K., Venette, J. R., Mc Mullen, M. P., Luecke, J. L., Glogonza, P. A., Grafton, K. F., and Berglund, D. R. 2000. 1999 dry bean grower survey of pest problems and pesticide use in Minnesota and North Dakota. N. D. State Univ. Ext. Rep. No. 47. Fargo, ND.

28. Miklas, P. N. 2000. Use of Phaseolus germplasm in breeding pinto, great northern, pink, and red beans for the Pacific Northwest and Inter-Mountain Region. Pages 13-29 in: Bean Research, Production, Utilization. S. Singh, ed. Proc. Idaho Bean Workshop, Twin Falls, ID.

29. Miklas, P. N., Larsen, K. M., Terpstra, K. A., Hauf, D. C., Grafton, K. F., and Kelly, J. D. 2007. QTL analysis of ICA-Bunsi-derived resistance to white mold in a pinto $\mathrm{x}$ navy bean cross. Crop Sci. 47:174-179.

30. Otto-Hanson, L. K., and Steadman, J. R. 2007. Identification of partial resistance to Sclerotinia sclerotiorum in dry bean at multiple locations in 2006. Annu. Rep. Bean Improv. Coop. 50:133-134.

31. Pariuad, B., Ravigne, V., Halkett, F., Goyeau, H., Carlier, J., and Lannou, C. 2009. Aggressiveness and its role in the adaptation of plant pathogens. Plant Pathol. 58:409-424.

32. SAS Institute Inc. 2003. The SAS System for Windows, Version 9.1. SAS Institute, Cary, NC.

33. Schwartz, H. F., Casciano, D. F., Asenga, J. A., and Wood, D. R. 1987. Field measurement of white mold effects upon dry beans with genetic resistance or upright plant architecture. Crop Sci. 27:669-702.

34. Steadman, J. R. 1979. Control of plant diseases caused by Sclerotinia species. Phytopathology 69:904-907.

35. Steadman, J. R., Otto-Hanson, L. K., and Breathnach, J. 2006. Identification of partial resistance to Sclerotinia sclerotiorum in dry bean at multiple locations in 2005. Annu. Rep. Bean Improv. Coop. 49:223-224.

36. Steadman, J. R., Otto-Hanson, L. K., and Powers, K. 2004. Identification of partial resistance to Sclerotinia sclerotiorum in dry bean at multiple locations. Annu. Rep. Bean Improv. Coop. 47:281-282.

37. Steadman, J. R., Otto-Hanson, L. K., and Powers, K. 2005. Identification of partial resistance to Sclerotinia sclerotiorum in dry bean at multiple locations in 2004. Annu. Rep. Bean Improv. Coop. 48:124-125.

38. Teran, H., Lema, M., Schwartz, H. F., Duncan, R., Gilbertson, R., an Singh, S. P. 2006. Modified Petzoldt and Dickson scale for white mold rating of dry bean. Annu. Rep. Bean Improv. Coop. 49:115-116.

39. Webster, D., Kelly, J. D. 2000. Commentary on germplasm enhancement and cultivar development. Pages 55-59 in: Bean Research, Production, Utilization. S. Singh, ed. Proc. Idaho Bean Workshop. Twin Falls, ID. 